\title{
Arsenic Speciation in Fish and Rice by HPLC-ICP-MS Using Salt Gradient Elution
}

\author{
Raquel Nogueira, ${ }^{*, a}$ Evyson A. Melo, ${ }^{a}$ Jefferson L. C. Figueiredo, ${ }^{a}$ Jéssica J. Santos ${ }^{a}$ and \\ Antonio P. do Nascimento Neto ${ }^{a}$ \\ ${ }^{a}$ Laboratório de Resíduos e Contaminantes (RES), Laboratório Nacional Agropecuário em Belém (LANAGRO/ \\ PA), Ministério da Agricultura, Pecuária e Abastecimento (MAPA), 66093-020 Belém-PA, Brazil
}

\begin{abstract}
This paper presents arsenic speciation studies by high-performance liquid chromatography with inductively coupled plasma-mass spectrometer (HPLC-ICP-MS) using a chromatography column containing a strong anion exchange stationary phase (Agilent Bio SAX G3154A/101) for determination of arsenobetaine (AsB), dimethylarsinic acid (DMA), As ${ }^{\mathrm{III}}$, monomethylarsonic acid (MMA), and $\mathrm{As}^{\mathrm{v}}$. The best separation was achieved in 15 min, using a 4 min isocratic step with $1 \mathrm{mM}\left(\mathrm{NH}_{4}\right)_{2} \mathrm{HPO}_{4} \mathrm{pH} 10.2$, followed by a 2 min salt gradient from 1 to $10 \mathrm{mM}$, which was kept for 4 min. Compared to the Food and Drug Administration (FDA) method for rice using the PRP-X-100 column, the Bio SAX method was quicker, provided at least equal separation of AsB from the next peak, and led to more symmetrical peaks. The linearity between 0.5 and $60 \mu \mathrm{g} \mathrm{L}^{-1}$ was shown. The method was tested with $10 \mu \mathrm{g} \mathrm{L}^{-1}$ fortified rice and fish samples extracted in ultrasound using methanol/water 1:1, and recoveries between 40 and $90 \%$ were obtained.
\end{abstract}

Keywords: arsenic speciation, high performance liquid chromatography with inductively coupled plasma mass spectrometry (HPLC-ICP-MS), strong anion exchanger (SAX), rice, fish

\section{Introduction}

Arsenic has mutagenic, teratogenic, genotoxic and neurotoxic effects, ${ }^{1}$ which depend directly on the arsenic species and their oxidation states. ${ }^{2,3}$ Inorganic As is classified as Group I carcinogen, ${ }^{4,5}$ being As ${ }^{\mathrm{III}}$ (arsenite) more toxic and more mobile than $\mathrm{As}^{\mathrm{V}}$ (arsenate). ${ }^{6-9}$ The inorganic arsenic species are hundreds of times more toxic than the organic species of monomethylarsonic acid $\left(\mathrm{MMA}^{\mathrm{v}}\right)$ and dimethylarsinic acid $\left(\mathrm{DMA}^{\mathrm{v}}\right),{ }^{10-12}$ while arsenobetaine (AsB) and arsenochloline (AsC), mostly found in fish and aquatic biota, are regarded as nontoxic. ${ }^{13-16}$ Arsenosugars (AsS), mostly found in marine algae, are of low toxicity. ${ }^{17,18}$

In nature, $\mathrm{As}^{\mathrm{III}}$ and $\mathrm{As}^{\mathrm{V}}$ are the predominant forms, mostly associated with soil minerals, but MMA and DMA can be formed by microbial action. ${ }^{19}$ Natural sources are responsible for $60 \%$ of the environmental contamination, ${ }^{1}$ and the common anthropogenic arsenic contamination sources include industrial wastes, mining, insecticides, fertilizers, and veterinary drug residues. ${ }^{20,21}$

Table 1 shows some of the important arsenic species.

Rice is a "bioaccumulative plant of the most toxic As

*e-mail: raquel.nogueira@agricultura.gov.br species". ${ }^{7}$ This is a matter of concern in Brazil, which is the eighth largest producer of rice. ${ }^{24}$ Seafood is another significant source of arsenic exposure for man. ${ }^{25,26}$ The WHO recommended limit for As in drinking water is $10 \mu \mathrm{g} \mathrm{L}{ }^{-1}{ }^{22}$ In rice, the limit for As according to WHO, Food and Drug Administration (FDA) and Codex Alimentarius is $200 \mu \mathrm{g} \mathrm{L}^{-1}\left(20 \mathrm{ng} \mathrm{g}^{-1}\right) .^{24}$ In Brazil, the Ministry of Agriculture, Livestock and Food Supply (MAPA) ${ }^{27}$ establishes a reference value for total As of $1000 \mu \mathrm{g} \mathrm{kg}^{-1}$ in kidney (bovine, pork, sheep), liver (poultry, rabbit), fish, and shrimps, as well as $300 \mu \mathrm{g} \mathrm{kg}^{-1}$ in honey.

High-performance liquid chromatography with inductively coupled plasma-mass spectrometer (HPLC-ICP-MS) is the most commonly used method to determine arsenic species, due to its wide dynamic range, high selectivity, high sensitivity (low detection limits), ${ }^{3}$ and capability to determine AsB and AsC, which cannot be analyzed by hydride generation techniques, since they do not form volatile hydrides by derivatization. ${ }^{28}$ Regarding the chromatographic separation, although reversed-phase stationary phases with ion-pairing agents have been used, ${ }^{29-31}$ ion-exchange chromatography is still the most extensively used technique. ${ }^{17}$

An HPLC-ICP-MS reference method for arsenic speciation in rice was published by the $\mathrm{FDA}^{32}$ in 2012 , 
Table 1. Examples of arsenic species ${ }^{3,11,22,23}$

\begin{tabular}{|c|c|c|c|c|}
\hline Species & Description & Molecular formula & CAS & Molecular mass \\
\hline \multirow{4}{*}{$A s^{I I I}$} & $\begin{array}{c}\mathrm{H}_{3} \mathrm{AsO}_{3}(\text { arsenous acid }) \\
\left(\mathrm{p} K_{\mathrm{a} 1}=9.2, \mathrm{p} K_{\mathrm{a} 2}=12.1, \mathrm{p} K_{\mathrm{a} 3}=13.4\right)\end{array}$ & & $13464-58-9$ & 125.94 \\
\hline & $\begin{array}{c}\mathrm{HAsO}_{2}(\operatorname{arsinic} \text { acid or arsonite }) \\
\left(\mathrm{p} K_{\mathrm{a}}=9.3\right)\end{array}$ & $\mathrm{O}=\mathrm{As}-\mathrm{OH}$ & - & - \\
\hline & $\mathrm{NaAsO}_{2}$ (sodium arsenite) & - & $7784-46-5$ & 129.91 \\
\hline & $\mathrm{As}_{2} \mathrm{O}_{3}$ (arsenic trioxide) & - & $7440-38-2$ & 74.92 \\
\hline \multirow[t]{2}{*}{$\mathrm{As}^{\mathrm{V}}$} & $\begin{array}{c}\mathrm{H}_{3} \mathrm{AsO}_{4}(\operatorname{arsenic} \text { acid }) \\
\left(\mathrm{p} K_{\mathrm{a} 1}=2.3, \mathrm{p} K_{\mathrm{a} 2}=6.9, \mathrm{p} K_{\mathrm{a} 3}=11.4\right)\end{array}$ & & $7778-39-4$ & 141.94 \\
\hline & $\mathrm{As}_{2} \mathrm{O}_{5}$ (arsenic pentoxide) & - & $\begin{array}{c}12044-50-7 \\
\left(. \mathrm{xH}_{2} \mathrm{O}\right)\end{array}$ & $\begin{array}{c}229.84 \\
\text { (anhydrous basis) } \\
\end{array}$ \\
\hline \multirow{3}{*}{ MMA } & \multirow{3}{*}{$\begin{array}{c}\text { monomethylarsonic acid }\left(\mathrm{MMA}^{\mathrm{V}}\right) \\
\left(\mathrm{CH}_{3} \mathrm{AsO}(\mathrm{OH})_{2}\right) \\
\left(\mathrm{p} K_{\mathrm{a} 1}=3.6, \mathrm{p} K_{\mathrm{a} 2}=8.2\right)\end{array}$} & & $124-58-3$ & 139.97 \\
\hline & & & $\begin{array}{l}\text { 144-21-8 } \\
\text { (disodium salt, } \\
\text { hexahydrate) }\end{array}$ & 292.02 \\
\hline & & & $\begin{array}{c}2163-80-6 \\
\text { (sodium salt) }\end{array}$ & 162.96 \\
\hline DMA & $\begin{array}{c}\text { dimethylarsinic acid }\left(\mathrm{DMA}^{\mathrm{v}}\right) \\
\left(\left(\mathrm{CH}_{3}\right)_{2} \mathrm{AsO}(\mathrm{OH})\right) \\
\left(\mathrm{p} K_{\mathrm{a} 1}=1.6, \mathrm{p} K_{\mathrm{a} 2}=6.2\right)\end{array}$ & $\mathrm{CH}_{3}$ & $\begin{array}{c}75-60-5 \\
124-65-2 \text { (sodium salt) }\end{array}$ & $\begin{array}{r}138.0 \\
159.98\end{array}$ \\
\hline AsB & $\begin{array}{l}\text { arsenobetaine }(\mathrm{AsB}) \\
\left(\left(\mathrm{CH}_{3}\right)_{3} \mathrm{As}^{+}\left(\mathrm{CH}_{2}\right)_{2} \mathrm{OH}\right) \\
\left(\mathrm{p} K_{\mathrm{a}}=4.7\right)\end{array}$ & $\mathrm{H}_{3} \mathrm{C}$ & $64436-13-1$ & 178.06 \\
\hline
\end{tabular}

MMA: monomethylarsonic acid; DMA: dimethylarsinic acid; AsB: arsenobetaine.

which uses a Hamilton PRP-X-100 column containing a strong anion exchange (SAX) stationary phase, operated in isocratic mode with $10 \mathrm{mM}$ ammonium phosphate $\mathrm{pH} 8.25$ during 20 min. Other authors ${ }^{33}$ have used the FDA method for arsenic speciation in seafood, but the $\mathrm{pH}$ of the mobile phase was adjusted to 8.65.

Since the Hamilton PRP-X-100 is the most commonly used column for arsenic speciation by ion-exchange HPLCICP-MS, laboratories depend on the purchase of this column to carry out speciation studies. In this work, we present the optimization experiments for the HPLC-ICP-MS separation of five arsenic species using another column, namely a strong anion exchanger from Agilent (Bio SAX), and the evaluation of the best experimental condition using $10 \mu \mathrm{g} \mathrm{\textrm {L } ^ { - 1 }}$ fortified rice and fish samples.

\section{Experimental}

\section{Instruments and apparatus}

Samples and standards were weighed in AUW 220D analytical balances (Shimadzu, São Paulo, Brazil). Sample solutions were evaporated in an EZ-2 Genevac centrifugal evaporator (Lobov Científica, São Paulo, Brazil).

An HPLC-ICP-MS from Agilent Technologies (São Paulo, Brazil) was used, consisting of 1260 Infinity Bio-inert high performance liquid chromatograph, equipped with quaternary pump with vacuum degasser (G5611A), autosampler (G5667A) and thermostated column compartment (G1316A), coupled to an ICP-MS 7700x with autosampler (G3281A) and chiller (G3292A), fitted with MicroMist glass concentric nebulizer and MassHunter Workstation. The vacuum mechanical pump was from Edwards (E2M18, Mid Sussex, England).

The HPLC column was an Agilent Bio strong anion exchanger (SAX) (G3154A/101, São Paulo, Brazil) in cross-linked and nonporous poly(styrene divinylbenzene) (PS/DVB), $250 \times 4.6 \mathrm{~mm}$ i.d., $10 \mu \mathrm{m}$ particle size (Agilent part number 5190-2475). An Agilent guard column $(50 \times 2 \mathrm{~mm})$ of the same material was used. The evaluated HPLC mobile phases consisted of ammonium phosphate solutions between 1 and $20 \mathrm{mM}$, with different $\mathrm{pH}$ values between 5.8 and 11.2. Until $\mathrm{pH} 8.3$, they were prepared by mixing monobasic and dibasic $\left(\mathrm{NH}_{4} \mathrm{H}_{2} \mathrm{PO}_{4}\right.$ and 
$\left.\left(\mathrm{NH}_{4}\right)_{2} \mathrm{HPO}_{4}\right)$ salt solutions with the same concentration, in the necessary proportions to reach the desired $\mathrm{pH}$ value. For $\mathrm{pH}$ values above 8.3 , the mobile phase was prepared by using only $\left(\mathrm{NH}_{4}\right)_{2} \mathrm{HPO}_{4}$ and the $\mathrm{pH}$ value was adjusted with ammonium hydroxide $25 \% \mathrm{v} \mathrm{v}^{-1}$. The best HPLC experimental condition is shown in Table 2.

Table 2. Optimized HPLC and ICP-MS conditions for arsenic speciation with the Agilent Bio SAX

\begin{tabular}{|c|c|}
\hline \multicolumn{2}{|l|}{ HPLC experimental condition } \\
\hline HPLC column & $\begin{array}{l}\text { Agilent Bio SAX G3154A/101, } \\
250 \times 4.6 \mathrm{~mm} \text { i.d., } 10 \mu \mathrm{m}\end{array}$ \\
\hline Mobile phase & $\begin{array}{l}\text { (A) } 1 \mathrm{mM}\left(\mathrm{NH}_{4}\right)_{2} \mathrm{HPO}_{4}, \mathrm{pH} 10.2 \\
\text { (B) } 10 \mathrm{mM}\left(\mathrm{NH}_{4}\right)_{2} \mathrm{HPO}_{4}, \mathrm{pH} 10.2\end{array}$ \\
\hline HPLC elution program & $\begin{array}{c}\text { 0-4 min: } 100 \% \mathrm{~A} \\
\text { 4-6 min: } 100 \% \text { A to } 100 \% \mathrm{~B} \\
\text { 6-10 min: } 100 \% \mathrm{~B} \\
10-12 \text { min: } 100 \% \text { B to } 100 \% \mathrm{~A} \\
12-15 \text { min: } 100 \% \mathrm{~A}\end{array}$ \\
\hline Flow-rate / $\left(\mathrm{mL} \mathrm{min}^{-1}\right)$ & 1 \\
\hline Column temperature $/{ }^{\circ} \mathrm{C}$ & 25 \\
\hline Injection volume / $\mu \mathrm{L}$ & 100 \\
\hline \multicolumn{2}{|l|}{$\begin{array}{l}\text { ICP-MS experimental } \\
\text { condition }\end{array}$} \\
\hline RF power / W & 1550 \\
\hline RF matching / V & 1.8 \\
\hline Sample depth / mm & 8 \\
\hline Plasma gas flow / (L min $\left.{ }^{-1}\right)$ & 15 \\
\hline $\begin{array}{l}\text { Nebulizer (carrier) gas flow / } \\
\left(\mathrm{L} \min ^{-1}\right)\end{array}$ & 0.95 \\
\hline Dilution gas flow / $\left(\mathrm{L} \mathrm{min}^{-1}\right)$ & 0.1 \\
\hline $\begin{array}{l}\text { Spray chamber temperature } \\
/{ }^{\circ} \mathrm{C}\end{array}$ & 2 \\
\hline Operation mode & helium mode $(\mathrm{He})$ \\
\hline He flow / $\left(\mathrm{mL} \mathrm{min}^{-1}\right)$ & 2.0 \\
\hline Collision cell & Oct bias -18 , Oct RF 190 , energy 5 \\
\hline Lenses & $\begin{array}{c}\text { E1 0, E2 }-180 \text {, OBias }-90 \text {, OL } 7 \text {, cell } \\
\text { entrance }-40 \text {, cell exit }-60, \mathrm{DE}-1.4 \text {, } \\
\text { plate bias }-60\end{array}$ \\
\hline Peristaltic pump speed / rps & $\begin{array}{c}0.3 \text { (ICP-MS hyphenated to HPLC) or } \\
0.1 \text { (not hyphenated) }\end{array}$ \\
\hline
\end{tabular}

HPLC: high-performance liquid chromatography, ICP-MS: inductively coupled plasma-mass spectrometer.

For the ICP-MS, the optimized conditions are summarized in Table 2. The arsenic species were detected at $m / z 75$. An aqueous solution containing $10 \mu \mathrm{g} \mathrm{L}^{-1} \mathrm{Y}^{89}, \mathrm{HNO}_{3}$ $0.5 \% \mathrm{v} \mathrm{v}^{-1}$, and isopropanol $1.5 \% \mathrm{v} \mathrm{v}^{-1}$ was used as internal standard. The peristaltic pump aspirated continuously the internal standard solution into the ICP-MS, and the software was programed to make the necessary adjustments in the arsenic readings according to the internal standard responses.

\section{Reagents and chemicals}

Ultrapure water (resistivity $18.2 \mathrm{M} \Omega \mathrm{cm}$ ) was obtained from a Purelab Ultra purification system (Elga LabWater, High Wycombe, United Kindgom) and used throughout. The evaluated arsenic species were: arsenobetaine (AsB) (CAS 64436-13-1) (95.8\%, Sigma-Aldrich, St. Louis, USA), sodium dimethyl arsinate (DMA) (CAS 124-65-2) (98.5\%, Dr. Ehrenstorfer, Teddington, Middlesex, UK), disodium methyl arsonate hexahydrate (MMA) (CAS 144-21-8) (99.5\%, Chem Service, West Chester, USA), As ${ }^{\mathrm{III}}$ (CAS 7440-38-2) (99.9\%, SPEX CertiPrep, Metuchen, USA), and As ${ }^{\mathrm{V}}$ (CAS 12044-50-7) (99.9\%, Sigma-Aldrich, St. Louis, USA).

Nitric acid $68 \% \mathrm{~m} \mathrm{~m}^{-1}$ (Merck, São Paulo, Brazil) was distilled twice prior to use. Methanol and acetonitrile (Merck, São Paulo, Brazil) were of HPLC grade. Dibasic ammonium phosphate (Vetec, Rio de Janeiro, Brazil), monobasic ammonium phosphate (Sigma-Aldrich, São Paulo, Brazil), and ammonium hydroxide $25 \% \mathrm{v} \mathrm{v}^{-1}$ (Merck, São Paulo, Brazil) were chemical grade.

\section{Preparation of standard solutions}

$\mathrm{As}^{\mathrm{III}}$ and $\mathrm{As}^{\mathrm{V}}$ were purchased as $1000 \mathrm{mg} \mathrm{L}^{-1}$ solutions. The other analytes (AsB, MMA, DMA) were purchased as solids, and individual $1000 \mathrm{mg} \mathrm{L}^{-1}$ stock solutions were prepared in water and kept in the freezer, in the dark. These solutions were prepared in polypropylene flasks, previously cleaned by leaching with $\mathrm{HNO}_{3} 10 \% \mathrm{v} \mathrm{v}^{-1}$ and rinsing with ultrapure water.

Intermediate aqueous standard solutions were prepared by dilution of each stock solution to $1 \mathrm{mg} \mathrm{L}^{-1}$. Aqueous mixtures containing all five arsenic species $\left(200 \mu \mathrm{g} \mathrm{L}^{-1}\right.$ of each species) were prepared daily. These mixtures were either used to fortify rice and fish samples, or further diluted to $0.5,2,10,20$ and $60 \mu \mathrm{g} \mathrm{L}-1$, which were the levels of the calibration curve.

\section{Sample preparation}

The procedure was based on the studies of Zheng and Hintelmann, ${ }^{34}$ which proposed three sequential extractions of arsenic species in ultrasound, using methanol/water 1:1. Rice and fish samples (10 $\mu \mathrm{g} \mathrm{L}^{-1}$ fortifications and blanks) were prepared as follows. Rice and fish amounts of $1.0 \mathrm{~g}$ were weighed into $50 \mathrm{~mL}$ Falcon tubes and then fortified with arsenic species, with exception of the blanks. The fortification was made by adding $1 \mathrm{~mL}$ of standard solution containing $200 \mu \mathrm{g} \mathrm{L}^{-1}$ of each arsenic species. To each tube containing the slurries (fortifications and blanks), $10 \mathrm{~mL}$ 
of methanol/water $1: 1 \mathrm{v} \mathrm{v}^{-1}$ were added. The slurries were mixed in vortex and kept in ultrasound during $20 \mathrm{~min}$ at room temperature. The matrices (rice or fish) were then separated from the solutions by centrifugation at $4,000 \mathrm{rpm}$, $20{ }^{\circ} \mathrm{C}$, for $10 \mathrm{~min}$. Two other extractions were performed as previously described, using $10 \mathrm{~mL}$ methanol/water 1:1, vortex and ultrasound ( $20 \mathrm{~min}$ ) each time. The three organic extracts were combined and the organic solvent was evaporated under vacuum at $40^{\circ} \mathrm{C}$ until the initial volume was reduced to $15 \mathrm{~mL}$. The solutions were transferred into $20 \mathrm{~mL}$ volumetric flasks (final solution volume), which were filled to the mark with water. Previous to the HPLC-ICP-MS analysis, the solutions were filtered through $0.45 \mu \mathrm{m}$ filters. The final theoretical concentration of each arsenic species was $10 \mu \mathrm{g} \mathrm{L} \mathrm{L}^{-1}$.

\section{Results and Discussion}

\section{HPLC-ICP-MS optimization for arsenic speciation}

The ICP-MS was optimized for the arsenic species according to Agilent procedures and the detailed optimized conditions are summarized in Table 2. No interference was observed due to the presence of chloride in the samples and formation of argon chloride $\left({ }^{40} \mathrm{Ar}^{35} \mathrm{Cl}^{+}\right.$at $\mathrm{m} / z$ 75 and ${ }^{40} \mathrm{Ar}^{37} \mathrm{Cl}^{+}$at $m / 277$ ), possibly due to the operation of the ICP-MS in helium collision cell mode, which was reported to eliminate interference from co-eluting chloride species. ${ }^{8,14,23,32}$

Optimization experiments of the chromatographic condition were carried to achieve the best separation of the five arsenic species using the Bio SAX column. The mobile phase was optimized regarding the buffer concentration (1 to $20 \mathrm{mM}$ ), the $\mathrm{pH}$ value (5.8 to 11.2 ), and organic solvent concentration (0-5\%). Additionally, isocratic and gradient elution modes were evaluated. The best obtained chromatographic condition is discussed in the next section. In this section, the observed behaviors of the arsenic species are presented and compared to previous literature studies.

Ammonium phosphate salts were chosen, since sodium salt buffers were reported to form residues in the sampler and skimmer cones, leading to signal drift and clogging problems in the ICP-MS, ${ }^{1,2}$ and also to suppress As signal. ${ }^{23}$ However, even without using sodium salts, the phosphates caused significant deposits on the cones and inside of the ICP-MS, as previously reported, ${ }^{1,12,35}$ creating the demand for equipment cleaning after $40 \mathrm{~h}$ of work (or after around 40 samples were analyzed).

The Agilent Bio SAX stationary phase is based on quaternary ammonium groups $\left(-\mathrm{N}^{+} \mathrm{R}_{3}\right)$, which are therefore expected to be positively charged in the whole $\mathrm{pH}$ range (2-12) of the chromatographic analysis.

The reduction of the buffer concentration (in the range between $20 \mathrm{M}$ and $1 \mathrm{mM}$ ) increased the retention of all arsenic species, as expected and previously reported, ${ }^{2,12}$ since the phosphate counter-ion is responsible for the elution of the negatively charged analytes retained on the positively charged anion-exchange (SAX) stationary phase. Concerning the separation, smaller phosphate concentrations improved the separation of the first eluted peaks, but also caused the broadening to the last eluted $\mathrm{As}^{\mathrm{V}}$ peak, as previously reported. ${ }^{12,36}$ Therefore, under isocratic conditions, the phosphate concentration (counterion) should be as small as possible to allow the separation of the first three eluted components (AsB, DMS, $\mathrm{As}^{\mathrm{III}}$ ), without causing their co-elution, but not so small to cause an excessive broadening of the $\mathrm{As}^{\mathrm{V}}$ peak and an increase in the run time. The possibility of using a salt gradient to minimize these problems was therefore considered (and successfully applied).

Some of the tested $\mathrm{pH}$ values included: 5.8, ${ }^{10,19,37} 6.2$, $7.9,{ }^{2} 8.25,{ }^{8,32} 10.2$ and 11.2. The $\mathrm{pH}$ values of 6.2 and 10.2, although not usually described in the literature, were chosen for being equal to $\mathrm{p} K_{\mathrm{a}}-1$ of $\mathrm{H}_{2} \mathrm{PO}_{4}^{-}\left(\mathrm{p} K_{\mathrm{a} 2}=7.2\right)$ and $\mathrm{p} K_{\mathrm{a}}+1$ of $\mathrm{NH}_{3}\left(\mathrm{p} K_{\mathrm{a}}=9.25\right)$, respectively. The use of strongly basic $\mathrm{pH}$ values is not frequently reported in arsenic speciation articles, but some authors ${ }^{1,27}$ were able to separate $\mathrm{As}^{\mathrm{III}}$ and AsB using SAX columns and phosphate buffer at high $\mathrm{pH}$ values, i.e., 10.7 .

MMA, DMA and $\mathrm{As}^{\mathrm{v}}$ have low $\mathrm{p} K_{\mathrm{a} 1}$ values (Figure 1) and, therefore, are usually present as negatively charged species (anions), which interact with the positively charged SAX column by ion-exchange mechanism. AsB is known as a zwitterion, due to the positive charge in arsenic and negative charge of carboxylic group $\left[\left(\mathrm{CH}_{3}\right)_{3} \mathrm{As}^{+} \mathrm{CH}_{2} \mathrm{COO}^{-}\right]^{6,23}$ Since $\mathrm{As}^{\mathrm{III}}$ has $\mathrm{p} K_{\mathrm{a}}=9.2$, it is present as a neutral species up to $\mathrm{pH} 8$ and "migrates almost with the solvent front". ${ }^{15}$ However, at $\mathrm{pH} 7.5$, arsenous acid starts to deprotonate and interacts with the positively charged stationary phase, causing a small increase in retention time. ${ }^{15}$

Under isocratic conditions, the addition of organic solvent to the mobile phase (methanol or acetonitrile $1 \% \mathrm{v} \mathrm{v}^{-1}$ ) increased As signal intensity (sensitivity), by making peaks sharper (higher $\mathrm{N}$ or plate number), without causing significant changes in the retention time, as previously reported. ${ }^{11,15,23}$ The organic solvent concentration should be small $\left(<5 \% \mathrm{v} \mathrm{v}^{-1}\right)$ to avoid plasma cooling and decrease in ionization efficiency. ${ }^{11}$ Additionally, it should be considered that most SAX columns are based on polymeric materials, which may be solvent sensitive. When using 


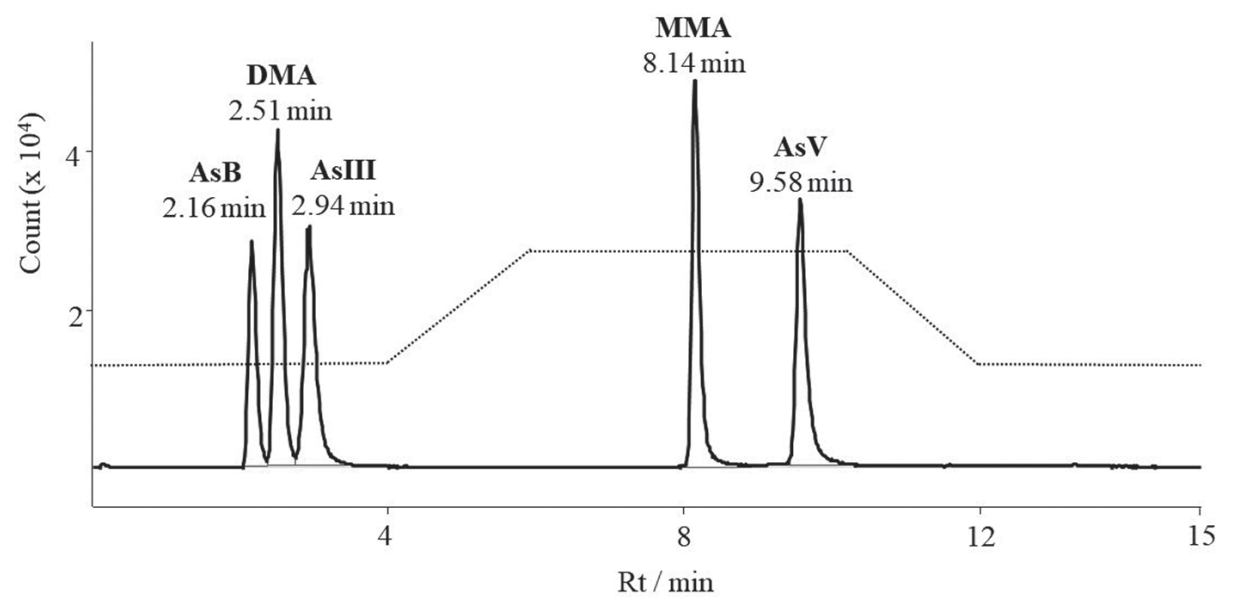

Figure 1. HPLC-ICP-MS chromatogram for arsenic species using the Agilent Bio SAX method. Experimental conditions: see Table 2 and Experimental section. AsB: arsenobetaine; DMA: dimethylarsinic acid; MMA: monomethylarsonic acid.

salt gradient elution, no need for organic solvent addition was verified, since the gradient itself was able to sharpen the peaks.

\section{Best HPLC-ICP-MS experimental condition for separation of} the five arsenic species using the Agilent Bio SAX column

The best experimental condition for HPLC-ICP-MS separation of the five arsenic species using the Agilent Bio SAX column is shown in Table 2. The initial isocratic step (1 mM, $4 \mathrm{~min}$ ) was necessary due to the AsB quick elution, and made possible its separation from the two next

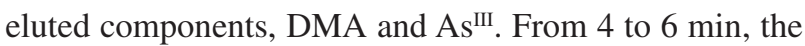
salt concentration was increased from 1 to $10 \mathrm{mM}$, which was maintained during the next $4 \mathrm{~min}$, in order to elute the strongly retained components MMA and $\mathrm{As}^{\mathrm{v}}$. Finally, the column was returned to the original condition, resulting in a total run time of $15 \mathrm{~min}$ (Figure 1).
Calibration curves were constructed using standard solutions containing $0.5,2,10,20$ and $60 \mu \mathrm{g} \mathrm{L} \mathrm{L}^{-1}$ of each arsenic species (Figure 2). Coefficients of determination $\left(\mathrm{R}^{2}\right)$ between 0.994 and 0.998 were obtained, demonstrating the linearity of the calibration curves from 0.5 to $60 \mu \mathrm{g} \mathrm{L}{ }^{-1}$.

Compared to the FDA separation (Figure 3), the Bio SAX separation shown in Figure 1 resulted in the reduction of the total run time from 20 to $15 \mathrm{~min}$, which represents a significant reduction in the ICP-MS argon consumption. Additionally, the visual separation of AsB from the next eluted component in Figure 1 was at least equal (or even better) than that shown in Figure 3. A numerical comparison of the separation degree was not possible, since the FDA did not report the resolution between the peaks. Another advantage of the Bio SAX separation is related to the peak shape, since more symmetrical peaks were obtained using this column (Figure 1) compared to the Hamilton column (Figure 3). It should also be noted
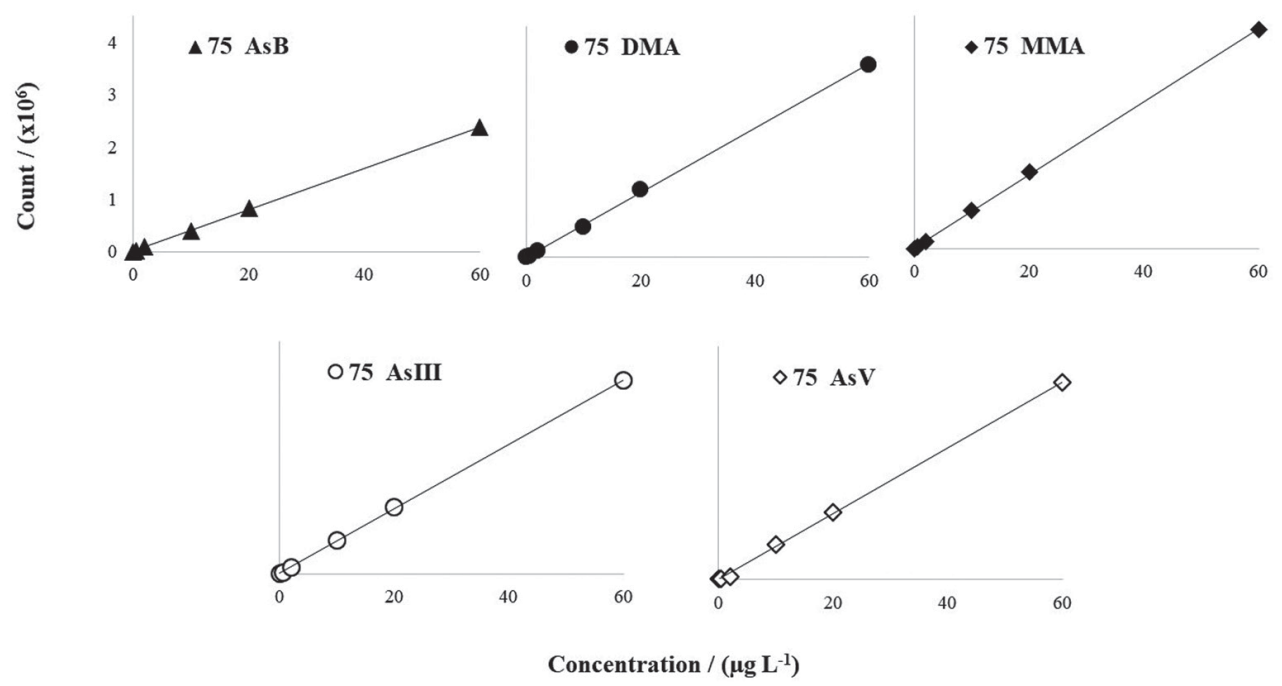

Figure 2. Calibration curves for the arsenic species using the Agilent Bio SAX column. Experimental conditions: see Table 2 and Experimental section. 
that the elution order in both columns was different: AsB, DMA, As ${ }^{\mathrm{III}}, \mathrm{MMA}$, and $\mathrm{As}^{\mathrm{V}}$ in the Bio SAX column, and $\mathrm{AsB}, \mathrm{As}{ }^{\mathrm{II}}$, DMA, MMA, and $\mathrm{As}^{\mathrm{V}}$ in the Hamilton column, which means, there was a change in the elution order of DMA and As ${ }^{\text {III }}$ peaks.

\section{Extraction and separation of arsenic species in rice and fish}

In order to test the separation of the arsenic species by HPLC-ICP-MS using the Bio SAX column, rice and fish samples were fortified with $10 \mu \mathrm{g} \mathrm{L}{ }^{-1}$ of each arsenic species (AsB, DMA, As ${ }^{\mathrm{III}}, \mathrm{MMA}$ and $\mathrm{As}^{\mathrm{v}}$ ) and then extracted, diluted and analyzed.

In the literature, ${ }^{7,34,38}$ the commonly used extraction methods for arsenic species are multiple extractions using methanol/water mixtures and mechanical agitation or sonication, as well as acidic digestion (nitric acid $0.15-0.28 \mathrm{~mol} \mathrm{~L}^{-1}$ or $1-2 \% \mathrm{v} \mathrm{v}^{-1}$ ) in water bath, microwave or digestion block (temperatures from 70 to $100{ }^{\circ} \mathrm{C}$ ).$^{23} \mathrm{Good}$ recoveries have been reported by using three successive extractions with methanol/water $1: 1 \mathrm{v} \mathrm{v}^{-1} .^{7,34,38}$

In our studies, several extraction procedures were tested, including the water bath acidic extraction reported by the FDA. ${ }^{32}$ The best arsenic recoveries, however, were obtained using a method adapted from Zheng and Hintelmann, ${ }^{34}$ consisting of three sequential ultrasound extractions
(20 min each) using methanol/water 1:1 (10 mL each). The obtained HPLC-ICP-MS chromatograms of fortified samples and blanks can be seen in Figure 4.

The main purpose of this study was to demonstrate that the Bio SAX method was able to separate the five arsenic species in rice and fish samples. This was accomplished as shown in Figure 4. Additionally, we present in Table 3 the obtained concentrations of arsenic species. The coefficients of variation $(\mathrm{CV})$ of the measured concentrations in the fortified samples were between 1.9 and $6.4 \%$ for rice and between 1.3 and $6.2 \%$ for fish. The recovery of each arsenic species was calculated by subtracting the concentration in the blank from the concentration in the fortified sample, and then dividing it by the theoretical concentration $\left(10 \mu \mathrm{g} \mathrm{L}^{-1}\right)$ (value expressed in percentage).

As can be seen in Table 3, the recoveries of arsenic species in fish were around $90 \%$, except for $\mathrm{As}^{\mathrm{III}}$ $\left(\mathrm{f}_{\mathrm{REC}}=40 \%\right)$, while the recoveries in rice were around $70 \%$, except for $\mathrm{As}^{\mathrm{V}}\left(\mathrm{f}_{\mathrm{REC}}=50 \%\right)$. The conversion from $\mathrm{As}^{\mathrm{III}}$ to $\mathrm{As}^{\mathrm{V}}$ is a commonly reported problem, ${ }^{7,10,19,36}$ but there was no evidence that it was the cause of the low As ${ }^{\text {III }}$ recovery in fish, since there was no simultaneous increase in the $\mathrm{As}^{\mathrm{v}}$ peak. The degradation by the ultrasound may be considered, since its use has been previously reported to affect the integrity of species. ${ }^{33}$ Therefore, there is still space for improvement in the used extraction procedure.

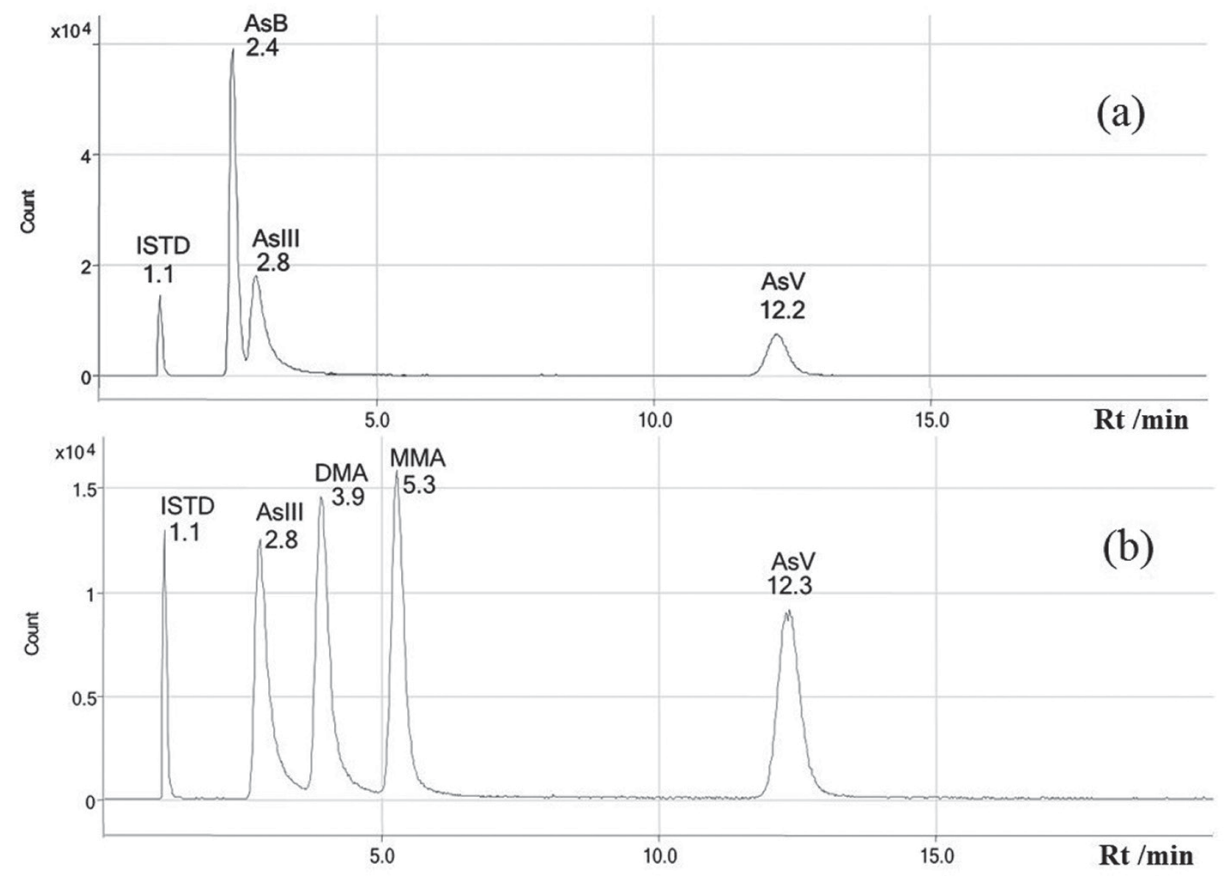

Figure 3. HPLC-ICP-MS chromatograms of arsenic species according to FDA method (adapted from reference 32). (a) Resolution solution containing $5 \mathrm{ng} \mathrm{g}^{-1} \mathrm{AsB}$ and $\mathrm{As}^{\mathrm{III}}$, with partial conversion of $\mathrm{As}^{\mathrm{III}}$ to $\mathrm{As}^{\mathrm{V}}$; (b) calibration standard containing $5 \mathrm{ng} \mathrm{g}^{-1}$ of each AsB, DMA, MMA, and As ${ }^{\mathrm{V}}$. HPLC experimental conditions: Hamilton PRP-X-100 column, $250 \times 4.1 \mathrm{~mm}$ i.d., $10 \mu \mathrm{m}$; mobile phase: $10 \mathrm{mM}\left(\mathrm{NH}_{4}\right)_{2} \mathrm{HPO}_{4}$, $\mathrm{pH} 8.25$ (adjusted with NH${ }_{4} \mathrm{OH}$ ); flow-rate $1 \mathrm{~mL} \mathrm{~min}^{-1}$; ambient temperature; injection volume $100 \mu \mathrm{L}$. ICP-MS conditions: RF power $1500 \mathrm{~W}$; plasma gas flow $15 \mathrm{~L} \mathrm{~min}^{-1}$; auxiliary gas flow $0.1 \mathrm{~L} \mathrm{~min}^{-1}$; nebulizer (carrier) gas $1.1 \mathrm{~L} \mathrm{~min}^{-1}$; sampling depth $8.5 \mathrm{~mm}$; He flow (collision cell) $2.0 \mathrm{~L} \mathrm{~min}{ }^{-1}$; spray chamber temperature $2{ }^{\circ} \mathrm{C}$; peristaltic pump speed 0.3 rps. AsB: arsenobetaine; DMA: dimethylarsinic acid; MMA: monomethylarsonic acid; ISTD: internal standard. 
(a) $10 \mu \mathrm{g} \mathrm{L}-1$ fortified rice
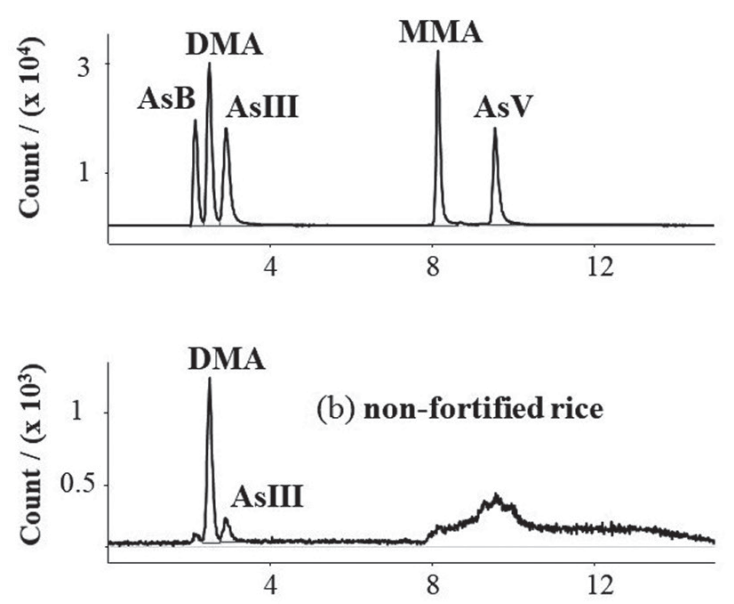

(c) $10 \mu g \mathrm{~L}^{-1}$ fortified fish
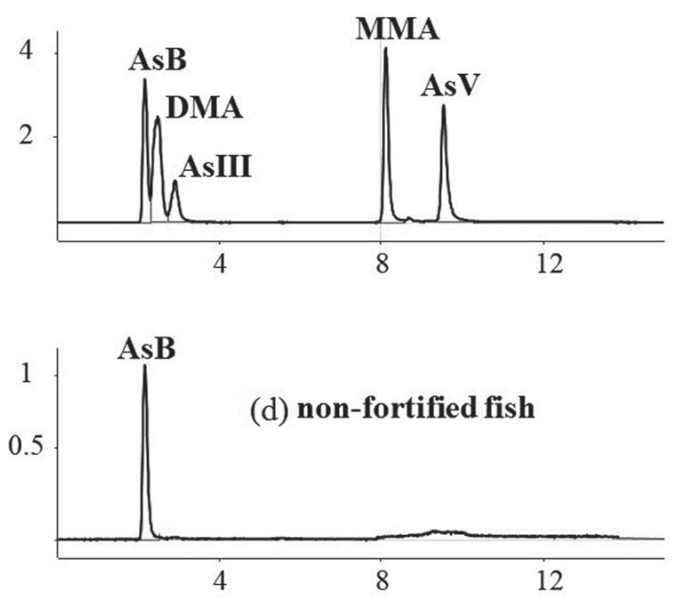

Time / $\min$

Figure 4. HPLC-ICP-MS chromatograms using the Bio SAX method for rice and fish samples fortified with $10 \mu \mathrm{L}^{-1}$ of AsB, DMA, As $s^{\mathrm{III}}$, MMA, and As ${ }^{\mathrm{V}}$ and extracted in ultrasound using methanol/water 1:1 $\mathrm{v} \mathrm{v}^{-1}$. Experimental conditions: see Table 2 and Experimental section. AsB: arsenobetaine; DMA: dimethylarsinic acid; MMA: monomethylarsonic acid.

Table 3. Recoveries $\left(\mathrm{f}_{\mathrm{REC}}\right.$ ) of arsenic species from $10 \mu \mathrm{g} \mathrm{L}-1$ fortified rice and fish samples extracted in ultrasound bath using methanol/water $1: 1 \mathrm{v} \mathrm{v}^{-1}$ and analyzed by HPLC-ICP-MS with Bio SAX column (recoveries estimated after sample blank subtraction)

\begin{tabular}{|c|c|c|c|c|c|c|c|c|c|c|}
\hline \multirow[b]{2}{*}{ Description } & \multicolumn{2}{|c|}{ AsB } & \multicolumn{2}{|c|}{ DMA } & \multicolumn{2}{|c|}{$\mathrm{As}^{\mathrm{III}}$} & \multicolumn{2}{|c|}{ MMA } & \multicolumn{2}{|c|}{$\mathrm{As}^{\mathrm{v}}$} \\
\hline & $\begin{array}{l}\text { Conc. / } \\
\left(\mu \mathrm{g} \mathrm{L}^{-1}\right)\end{array}$ & $\begin{array}{c}\mathrm{f}_{\mathrm{REC}} / \\
\%\end{array}$ & $\begin{array}{l}\text { Conc. / } \\
\left(\mu g L^{-1}\right)\end{array}$ & $\begin{array}{c}\mathrm{f}_{\mathrm{REC}} / \\
\%\end{array}$ & $\begin{array}{l}\text { Conc. / } \\
\left(\mu g L^{-1}\right)\end{array}$ & $\begin{array}{c}\mathrm{f}_{\mathrm{REC}} / \\
\%\end{array}$ & $\begin{array}{l}\text { Conc. / } \\
\left(\mu g L^{-1}\right)\end{array}$ & $\begin{array}{c}\mathrm{f}_{\mathrm{REC}} / \\
\%\end{array}$ & $\begin{array}{l}\text { Conc. / } \\
\left(\mu g L^{-1}\right)\end{array}$ & $\begin{array}{c}\mathrm{f}_{\mathrm{REC}} \mathrm{d} \\
\%\end{array}$ \\
\hline Non-fortified rice & 0 & - & 0.33 & & 0.07 & - & 0 & - & 0 & - \\
\hline $10 \mu \mathrm{g} \mathrm{L}^{-1}$ fortified rice & 7.37 & 73.7 & 7.93 & 76.0 & 6.72 & 65.5 & 6.73 & 67.3 & 5.48 & 54.8 \\
\hline Non-fortified fish & 3.07 & - & 0 & - & 0 & - & 0 & - & 0 & - \\
\hline $10 \mu \mathrm{g} \mathrm{L}^{-1}$ fortified fish & 12.32 & 92.5 & 9.87 & 98.7 & 3.85 & 38.5 & 9.34 & 93.4 & 8.76 & 87.6 \\
\hline
\end{tabular}

Conc.: concentration; $\mathrm{f}_{\mathrm{REC}}$ : recovery factor.

\section{Conclusions}

An HPLC-ICP-MS method for arsenic speciation was developed using an Agilent Bio SAX column, based on ammonium phosphate salt gradient elution (1 to $10 \mathrm{mM}$ ) at $\mathrm{pH} 10.2$, which is an alternative to methods using the Hamilton PRP-X-100 column, commonly operated under isocratic conditions at $\mathrm{pH} 8.25$, as in the FDA reference method for rice. The Bio SAX method represents an economy in the argon gas consumption, since the total run time was reduced from 20 to $15 \mathrm{~min}$, and provides at least equal separation of the five arsenic species AsB, DMA, $A s^{\text {III }}$, MMA, and As ${ }^{\mathrm{V}}$ compared to the FDA method, with more symmetric peak shapes.

The method was tested using fortified rice and fish samples, extracted in ultrasound using methanol/water $1: 1$, and recoveries between 40 and $90 \%$ of the species were obtained.

\section{Acknowledgments}

The authors would like to thank LANAGRO-SP for the support.

\section{References}

1. Ammann, A. A.; Am. J. Anal. Chem. 2011, 2, 27.

2. Chen, Z.; Akter, K. F.; Rahman, M. M.; Naidu, R.; J. Sep. Sci. 2006, 29, 2671.

3. Nearing, M. M.; Koch, I.; Reimer, K. J.; Spectrochim. Acta, Part B 2014, 99, 150.

4. Chen, M.-L.; Ma, L.-Y.; Chen, X.-W.; Talanta 2014, 125, 78.

5. Sun, G.; Williams, P. N.; Carey, A.; Zhu, Y.; Deacon, C.; Raab, A.; Feldmann, J.; Islam, R. M.; Meharg, A. A.; Environ. Sci. Technol. 2008, 42, 7542.

6. Barra, C. M.; Santelli, R. E.; Abrão, J. J.; la Guardia, M.; Quim. Nova 2000, 23, 58. 
7. Pizzaro, I.; Gómez, M.; Cámara, C.; Palacios, M. A.; Anal. Chim. Acta 2003, 495, 85.

8. Juskelis, R.; Li, W.; Nelson, J.; Cappozzo, J. C.; J. Agric. Food Chem. 2013, 61, 10670.

9. Correia, C. L. T.; Gonçalves, R. A.; Azevedo, M. S.; Vieira, M. A.; Campos, R. C.; Microchem. J. 2010, 96, 157.

10. Zmozinski, A. V.; Llorente-Mirantes, T.; López-Sánchez, J. F.; da Silva, M. M.; Food Chem. 2015, 173, 1073.

11. Demesmay, C.; Olle, M.; Porthault, M.; Fresenius' J. Anal. Chem. 1994, 348, 205.

12. Milstein, L. S.; Essader, A.; Pellizzari, E. D.; Fernando, R. A.; Akinbo, O.; Environ. Int. 2002, 28, 277.

13. McSheehy, S.; Szpunar, J.; J. Anal. At. Spectrom. 2000, 15, 79.

14. Day, J. A.; Montes-Bayón, M.; Vonderheide, A. P.; Caruso, J. A.; Anal. Bioanal. Chem. 2002, 373, 664.

15. Raber, G.; Francesconi, K. A.; Irgolic, K. J.; Goessler, W.; Fresenius' J. Anal. Chem. 2000, 367, 181.

16. Serafimovski, I.; Karadjova, I. B.; Stafilov, T.; Tsalev, D. L.; Microchem. J. 2006, 83, 55.

17. Pétursdóttir, A. H.; Gunnlaugsdóttir, H.; Krupp, E. M.; Feldmann, J.; Food Chem. 2014, 150, 353.

18. Contreras-Acuna, M.; Garcia-Barrera, T.; Garcia-Sevillano, M. A.; Gomez-Ariza, J. L.; J. Chromatogr. A 2013, 1282, 133.

19. Al-Assaf, K. H.; Tyson, J. F.; Uden, P. C.; J. Anal. At. Spectrom. 2009, 24, 376.

20. Batista, B. L.; Souza, J. M. O.; Souza, S. S.; Barbosa, F.; J. Hazard. Mater. 2011, 191, 342.

21. Moreira, C. M.; Duarte, F. A.; Lebherz, J.; Pozebon, D.; Flores, E. M. M.; Dressler, V. L.; Food Chem. 2011, 126, 1406.

22. Le, X. C.; Xiufen, L.; Xing-Fang, L.; Anal. Chem. 2004, 1, 27 A.

23. Maher, W. A.; Ellwood, M. J.; Krikowa, F.; Raber, G.; Foster, S.; J. Anal. At. Spectrom. 2015, 30, 2129.

24. Cerveira, C.; Pozebon, D.; Pompéu, D. M.; Fraga, J. C. S.; Anal. Methods 2015, 7, 4528.

25. Karadjova, I. B.; Petrov, P. K.; Serafimovski, I.; Stafilov, T.; Tsalev, D.; Spectrochim. Acta, Part B 2007, 62, 258.

26. Shah, A. Q.; Kazi, T. G.; Baig, J. A.; Arain, M. B.; Afridi, H. I.; Kandhro, G. A.; Wadhwa, S. K.; Kolachi, N. F.; Food Chem. 2010, 110, 840 .
27. Ministério da Agricultura, Pecuária e Abastecimento (MAPA), Secretaria de Defesa Agropecuária (SDA), Instrução Normativa No. 13, de 15 de julho de 2015 Publica o Subprograma de Monitoramento e Subprograma Exploratório do Plano Nacional de Resíduos e Contaminantes (PNCRC) de 2015 para as Cadeias de Carnes Bovina, Suína, Caprina, Ovina, Equina, Coelho, Aves, Avestruz, de Leite, Pescado, Mel e Ovos; Diário Oficial da União, Brasília, 15 de julho de 2015.

28. Martín, I.; López-Gonzálvez, M. A.; Gómez, M.; Cámara, C.; Palacios, M. A.; J. Chromatogr. B 1995, 666, 101.

29. Kai, N.; Man, H.; Beiben, C.; Yujie, C.; Bin, H.; Talanta 2018, 183, 48.

30. Araujo-Barbosa, U.; Pena-Vazquez, E.; Barciela-Alonso, M. C.; Ferreira, S. L. C.; dos Santos, A. M. P.; Bermejo-Barrera, P.; Talanta 2017, 70, 523.

31. Jeong, S.; Lee, H.; Kim, Y.-T.; Yoon, H.-O.; Microchem. J. 2017, 134, 295.

32. Kubachka, K. M.; Shockey, N. V.; Hanley, T. A.; Conklin, S. D.; Heitkemper, D. T.; Elemental Analysis Manual for Food and Related Products, version draft 1.1, Food and Drug Administration, 2012.

33. Schmidt, L.; Landero, J. A.; Novo, D. L. R.; Duarte, F. A.; Mesko, M. F.; Caruso, J. A.; Flores, E. M. M.; Food Chem. 2018, 255, 340 .

34. Zheng, J.; Hintelmann, H.; J. Anal. At. Spectrom. 2004, 19, 191.

35. Sawerwyns, S.; Zhang, X.; Vanhaecke, F.; Cornelis, R.; Moens, L.; Dams, R.; J. Anal. At. Spectrom. 1997, 12, 1047.

36. Segura, M.; Munoz, J.; Madrid, Y.; Cámara, C.; Anal. Bioanal. Chem. 2002, 374, 513.

37. Llorente-Mirandes, T.; Ruiz-Chancho, M. J.; Barbero, M.; Rubio, R.; Chemosphere 2010, 81, 867.

38. Praposki, R. E.; Le, X. C.; Anal. Chim. Acta 2004, 526, 69.

Submitted: March 14, 2018

Published online: May 11, 2018 